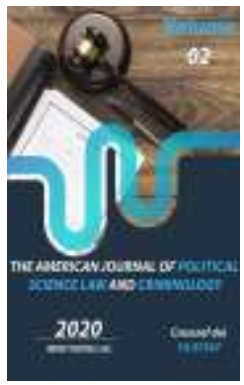

\section{"Theoretical And Legal Issues To Increase The Efficiency Of Criminal Prevention Activities Of Investigation Departments"}

\author{
Sultonov Oybek Sultonboevich \\ Academy Of The Prosecutor General's Office Of The Republic Of Uzbekistan \\ Independent Researcher, Uzbekistan
}

Journal Website: http://usajournalshub.c om/index,php/tajpslc

Copyright: Original content from this work may be used under the terms of the creative commons attributes 4.0 licence.

\title{
ABSTRACT
}

The article highlights the meaning and foundations of the effective organization of preventive activities of investigative units in the fight against crime in the Republic of Uzbekistan.

In this regard, the current state of law enforcement practice on the organization of preventive work in the investigation of crimes was studied and the problems existing in practice were indicated.

The article also provides an analysis of the foundations of the use of forensic methods in the organization of preventive activities of investigative units, the foundations of the widespread use of modern information technologies in this area.

\section{KEYWORDS}

Crime, prevention, forensic methods, modeling, information technology.

\section{INTRODUCTION}

Today, crime is a threat to global security as a dangerous socio-technological process in its development trends around the world. This, in turn, puts on the agenda one of the main tasks - to improve the fight against crime.

Therefore, the analysis of the effective functioning of the system of combating crime in legal science is one of the most important issues of scientific and practical significance today.

In this regard, if we analyze the basics of crime prevention activities of investigative units, we can see the importance of forensic measures in the activities of investigative units.

In particular, in this regard, the lawyer I.R.Verenchikov believes that forensic activity 
is one of the most effective measures in the fight against crime, in this regard, the prevention of crime, the elimination of the causes and conditions that led to the crime.

According to legal scientist GM Shapovalova, the current work in the fight against crime in the law enforcement system lags behind the trend of crime.

Therefore, in the opinion of the scientist, special attention should be paid to the use of modern information technology in the organization of preventive activities in the investigation of crimes.

Today, the main task of law enforcement agencies is inextricably linked with the effective functioning of the system of preventive measures aimed at preventing crime.

In this direction, significant work is being done in our country to combat crime.

However, there are still pressing issues that need to be addressed in the field.

In particular, 20,497 crimes or $95.2 \%$ of the total crimes were detected in the country in the first six months of 2020. Investigators arrested 1,051 wanted persons and found 261 missing persons.

At the initiative of law enforcement agencies, 4158 crimes were detected. Crime was not allowed in $66.3 \%$ or 6061 out of 9145 mahallas of the country.

At the same time, in the first six months of this year, 21,535 crimes were registered in the country, which is an average of 63.3 per 100,000 population.

Serious crimes are being committed as a result of unrest in families, untimely resolution of disputes, and neglect of community activists and the general public.
In particular, in the first six months of 2020 , one in three homicides ( 71 cases, 35\%) and 76 cases of grievous bodily harm (20.5\%) were committed within the family.

At the same time, as a result of untimely settlement of family disputes, 5,940 violations of family relations were committed, the majority of which, or $52.6 \%(3,123)$, were in Tashkent, Bukhara, Navoi and Fergana regions.

In this regard, 2,776 women who were subjected to domestic violence were issued "protection orders".

Due to the fact that there are still many problems in working with young people, not enough attention is paid to solving them, in the first 6 months of this year, every fourth crime (4988 or $23.2 \%$ ) was committed by young people, of which 1315 or $6 \%$ were employed. committed by unemployed youth.

In addition, the fact that more than 3,000 $(3,198)$ unemployed have committed crimes shows that employment issues are not being effectively addressed.

Although the total number of road accidents in the country decreased compared to the same period last year (2564/2388), 730 people died as a result of inadequate road safety. 2,297 were injured to varying degrees.

At the same time, the fact that almost every second (1017 out of 2388) traffic accidents occurred as a result of increasing the speed limit indicates the need to further accelerate the use of photo and video recording devices in the field.

An analysis of these cases shows that the system of preventive measures to prevent crime has the following shortcomings:

- The system of legislation on the organization of preventive activities in the investigation of crimes does not fully take 
into account the requirements of today's law enforcement practice;

- Due to the poor system of public relations for the organization of preventive activities in the investigation of crimes, as well as the low level of public awareness of the activities of investigative bodies in this area, public participation in preventive activities does not give the expected results;

- The state of human resources in the system does not meet today's requirements of modern management;

- The existing legal, material, technical and other financial issues in the system of law enforcement agencies on the widespread use of modern technologies for the effective organization of preventive activities in the investigation of crimes are not fully resolved.

Effective organization of preventive activities in the investigation of crimes requires an analysis of the scientific and practical basis for addressing these issues.

In this regard, the legal scientist N.D. Slyusareva believes that the current crisis in the global economic, political and social systems leads to a worsening of the criminogenic situation .

According to researchers, one of the biggest shortcomings in the work of law enforcement agencies in the fight against crime is due to the priority given to the criminal justice system in dealing with the criminogenic situation.

In this regard, according to legal scholars S.S. Galakhov and V.I. Kozlov, "no matter how effective the system of criminal penalties, it will not have enough influence to curb crime at a sustainable level" .

Of course, respecting the opinion of these scholars, it can be said that the criminal justice system is also primarily aimed at crime prevention, in which the functions of the state in law enforcement and crime prevention are implemented through the application of punishment.

Only in our opinion, in order to prevent the application of criminal sanctions in the prevention of crime, it is necessary to effectively implement preventive measures in criminal proceedings in the manner prescribed by procedural legislation.

In particular, the effective organization of work in the field of crime prevention will have to take into account the results of reforms in the law enforcement system, based on the requirements of internationally recognized advanced international standards .

Тергов бўлинмаларининг жиноятларни профилактика қилиш фаолиятини амалга оширишнинг процессуал тартибининг мазмуни терговчининг бу борадаги хуқуқий мақоми билан боғлиқдир.

As noted above, the investigator, within the scope of his powers set forth in Article 36 of the Criminal Procedure Code of the Republic of Uzbekistan, in addition to determining the causes and circumstances that led to the commission of crimes in the investigation of crimes, provides a legal assessment of the activities of state bodies, officials and public structures responsible for the prevention of offenses to prevent the causes and conditions that lead to crimes.

In this regard, the investigator's systematic analysis of the causes and circumstances that led to the crime, allowing to fully reveal the essence of the crime and its mechanisms of commission, serves as a basis for the development of measures to eliminate these causes and conditions and to prevent their occurrence in the future. 
The forensical basis of crime prevention activities of investigative units is related to the collection and analysis of information on the forensic description of crimes, in this regard, the methods of committing crimes, their causes and the circumstances that led to them are studied.

In this regard, legal scholars R.A. Alimova and A.N. Norboev believe that in order to facilitate the use of forensic methodological recommendations in the detection, investigation and prevention of crimes, they should adhere to the principle of constructive unity of private methods, ie internal independence and diversity it is necessary to adhere to the optimal structure.

Investigative practice requires the creation of specific forensic methods that take into account the content of the investigative situations that are typical for each type of crime and recommend one or another method of organizing the investigation in connection with it. The investigation situation in a criminal case consists of a set of circumstances (conditions, factors) that characterize the situation at a particular stage of the criminal investigation.

Typical investigative situations are specific to all stages of criminal investigation, but forensic methods often analyze the initial typical investigative situations. Their diversity requires many different recommendations and the development of their systems. The development of methods of criminal investigation, taking into account the typical circumstances of the investigation, clarifies the content of the recommendations and increases their practical value.

Therefore, according to some scholars, the criminological basis of crime prevention is of practical importance in the fight against crime
The need to use forensic measures in the implementation of preventive activities in the investigation of crimes is due to the fact that the causes and conditions that led to the commission of crimes are determined by the widespread use of forensic techniques.

Accordingly, in law researches, the investigative activities of investigative units are sometimes referred to as forensic prevention.

In this regard, the legal scientist V.N. Bodyakov believes that forensic prevention as part of the overall system of legal prevention includes special tools and methods for determining the causes and conditions that allow the commission of crimes.

This system of special tools and methods serves as a basis for the detection and prevention of criminal activity of individuals or criminal groups .

One of the most widely used methods in the investigation of crimes in the system of forensic prevention is forensic modeling.

Forensic modeling includes the following methods of scientific knowledge:

- Analysis;

- Recognition;

- Analogy;

- Forecasting.

In this regard, according to the legal scientist O.A. Berzin, the method of forensic modeling plays an important scientific and practical role in the full study of the objective circumstances of the crime, the restoration of the state of the crime .

Summarizing the above points, it can be said that the application of forensic modeling method plays an important role in increasing the effectiveness of crime detection and detection activities. 
This is because the causes and conditions that led to the commission of crimes, the motivation for the commission of crimes are quickly and fully identified through the use of forensic modeling in the organization of preventive activities in the investigation of crimes.

The data obtained as a result of the application of forensic modeling methods not only allow to identify and expose the crimes committed, but also serve as a basis for important scientific and practical recommendations for the prevention of this type of crime in the future.

Effective organization of preventive activities in the investigation of crimes requires the effective use of the results of scientific and technological advances, in particular, modern information technology.

In this regard, the lawyer B. Pulatov believes that the introduction of modern advanced methods in the investigation of crimes in the economic sphere should play a special role in law enforcement. Privatization has led to an increase in the number of previously unknown or very rare crimes in social development processes, including domestic and foreign economies. Illegal actions in the stock market and banking, violation of customs legislation, concealment of income, fraudulent bankruptcy, concealment of bankruptcy and other similar crimes require investigators and prosecutors to acquire new knowledge and a new approach to their investigation. The investigation of this category of cases will require the involvement of relevant specialists, extensive use of scientific, technical and forensic tools .

In addition to this view, it can be said that the elimination of threats to the global security system posed by modern crime today cannot be achieved without the use of forensic techniques based on scientific and technological advances.

The issues of effective organization of preventive activities in the investigation of crimes have been constantly studied in legal science.

In this regard, in our opinion, it should be borne in mind that today the possibilities of modern information and communication technologies, especially global and social networks, to directly influence the daily lives, social outlook and lifestyle of citizens have greatly expanded.

Summarizing the above, the following measures are proposed for the widespread use of modern information technology for the effective organization of preventive activities in the investigation of crimes:

First, the use of social networks, official websites of government agencies, educational institutions in the effective organization of preventive activities in the investigation of crimes;

Second, the creation of special forensic Internet resources for the effective organization of preventive activities in the investigation of crimes.

Third, conduct regular training sessions with investigators on the widespread use of modern information technology in the effective organization of preventive activities in the investigation of crimes.

\section{REFERENCES}

1. See: Verentchikov I.R. Preventive activities of the investigator (forensic aspect): abstract of thesis ... candidate of legal sciences. Minsk, 1990. C.18 // Verentchikov I.R. Preventive activity of the investigator (forensic aspect): abstract of thesis ... candidate of legal sciences. Minsk, 1990. P.18 
2. Shapovalova G.M. Forensics and its role in crime prevention based on information technologies // Police activity. \# 2. 2016.S. 187 // Shapovalova G.M. Criminalistics and its role in crime prevention based on information technologies // Police activity. N 2..2016. P.187

3. Report of the Minister of Internal Affairs of the Republic of Uzbekistan to the Senate of the Oliy Majlis on the state of crime and delinquency prevention for 6 months of 2020 //http://senat.uz/uz/lists/view/1725

4. Slyusareva ND Forensic support for the investigation of crimes against the family: abstract of thesis ... cand. jurid. sciences. M., 2013.C.28 // Slyusareva N.D. Forensic support for the investigation of crimes against the family: abstract of thesis ... cand. jurid. sciences. M., 2013. P. 28

5. Galakhov S.S., Kozlov V.I. Problems and Prospects for Crime Prevention // Societies and Law. 2009 No. 4 (26). S.161-166. // Galakhov S.S., Kozlov V.I. Problems and prospects of crime prevention // Societies and law. 2009 No. 4 (26). P.161-166

6. Shapovalova G.M. Forensics and its role in crime prevention based on information technologies // Police activity. \# 2. 2016.S. 189 // // Shapovalova G.M. Criminalistics and its role in crime prevention based on information technologies // Police activity. N 2..2016. P.187

7. Alimova R. A., Norboev. A.N. Methods of crime investigation. Study guide. - T.: TSU Publishing House, 2007. P / 18 /

8. Ivanov I.I. Forensic prevention (a comprehensive study of genesis, state, prospects): dissertation ... d.ra. jurid. sciences. SPb .., 2004. P.418 // Ivanov I.I. Forensic prevention (a comprehensive study of genesis, state, prospects): dissertation ... d.ra. jurid. sciences. SPb .., 2004. P.418
9. Bodyakov V.N. Issues of organizing preventive and prophylactic activities in the process of disclosing and investigating crimes committed by officials of the UIS of Russia // Actual problems of Russian law. 2007. No. 2 (5). Pp. 382-387 // Bodyakov V.N. Issues of organizing preventive and preventive activities in the process of disclosing and investigating crimes committed by officials of the penitentiary system of Russia // Actual problems of Russian law. 2007. No. 2 (5). P.382-387

10. Berzin. O. A. Forensic approaches to modeling criminal activity // Law. Journal of the Higher School of Economics. 2011. No. 4. S. 133-143. // Berzin. O. A. Forensic approaches to modeling criminal activity // Law. Journal of the Higher School of Economics. 2011. No. 4.P. 133-143

11. Po'latov B.X. Prosecutorial control over the implementation of laws by law enforcement agencies // Textbook // Journal "Law and Duty". 2007. P.96. 